\title{
Temporalidades amazônicas: uma contribuição à Ecologia Política
}

\section{Amazonian Temporalities: A Contribution to Political Ecology}

\author{
Carlos Walter PORTO-GONÇALVES*
}

\begin{abstract}
RESUMO
$\mathrm{O}$ artigo que ora se apresenta tem como foco as múltiplas temporalidades amazônicas, dos pontos de vista geológico, geomorfológico, arqueológico, antropológico e histórico e suas expressões temporais atuais. Resultante de um conjunto de conferências sobre a temática com base numa avaliação do pensamento político crítico e da crise civilizacional, coloca em realce duas matrizes de conhecimento a partir de várias contribuições científicas recentes e do rico conhecimento que advém dos diversos povos que vivem na Amazônia. Balizado no diálogo de saberes, o artigo propõe a formulação de outra política em relação à região que aponte para um novo porvir.
\end{abstract}

Palavras-chave: temporalidades; sociedade e natureza; floresta amazônica; movimentos sociais; diálogo de saberes.

\begin{abstract}
This article is focused on the multiple Amazonian temporalities. It is based on various conferences about the theme. These temporalities are considered in the geological, geomorphologic, archeological and historical points of view, as well as in their present expressions. Two main knowledge matrixes were considered: the recent scientific contribution and the rich knowledge proceeding from the traditional populations living in the region. They are evaluated concerning the political-critical thinking and in the light of the civilization crisis. The article proposes the formulation of a new policy for the region based on the dialog between traditional and scientific knowledges.
\end{abstract}

Key words: temporalities; society and nature; Amazonian forest; social movements; multiple knowledge-based dialog.

\footnotetext{
* Doutor em Geografia e Professor do Programa de Pós-graduação em Geografia da Universidade Federal Fluminense e Pesquisador do CNPq - Conselho nacional de Desenvolvimento Científico e Tecnológico - e do Grupo Hegemonia e Emancipações de Clacso. Ganhador do Prêmio Casa de las Américas 2008 de Literatura Brasileira. Ex-Presidente da Associação dos Geógrafos Brasileiros (1998-2000). Membro do Grupo de Assessores do Mestrado em Educação Ambiental da Universidade Autônoma da Cidade do México. Ganhador do Prêmio Chico Mendes em Ciência e Tecnologia em 2004, é autor de diversos artigos e livros publicados em revistas científicas nacionais e internacionais. Contato: cwpg@uol.com.br.
} 
Uma sociedade que, quando olha para uma floresta, vê metro cúbico de madeira; quando olha para um rio, vê megawatts de energia; que olha para a montanha e vê toneladas de cassiterita, ouro e prata, já perdeu a condição de perceber a dimensão profunda da natureza.

Aílton Krenac

\section{Observações preliminares}

No presente artigo, retomo notas que reuni para um conjunto de conferências sobre a Amazônia realizadas em várias universidades do Brasil, da América Latina e na Galícia (Espanha) entre 2001 e 2005. Aproveito este momento para incorporar um conjunto de inquietações que foram manifestadas por intelectuais e ativistas que têm dedicado atenção à região. O leitor deve ter em conta que muitas das idéias foram extraídas de transcrições de algumas dessas conferências.

Neste artigo, parto de uma avaliação de que o pensamento político crítico, sobretudo de esquerda, não tem levado em conta (1) um conjunto de contribuições científicas recentes e (2) a rica contribuição do conhecimento que advém dos diferentes povos que vivem na Amazônia, sobretudo camponeses e povos originários, conhecimentos esses produzidos em situação de conflito intenso. Considero essas duas matrizes de conhecimento importantíssimas para que possamos formular outra política com relação a essa região (observo que evito dizer para a região ou sobre a região). Tento aqui reunir o que de melhor vem dessas duas fontes, fruto de aproximadamente 30 anos em que tenho me envolvido com essas populações e com as pesquisas que, por conta desse envolvimento, venho fazendo durante todo esse tempo.

\section{Os múltiplos tempos do espaço amazônico}

O saudoso geógrafo Milton Santos afirmou certa vez que o espaço geográfico é uma acumulação de tempos. No espaço convivem simultaneamente diferentes temporalidades. É com essa inspiração teórica que ofereço a leitura da Amazônia que segue.

Quando se fala da Amazônia, todas as questões parecem se tornar megalômanas. Considerando a Amazônia enquanto um ecossistema de floresta tropical úmida, chegase a uma área equivalente a 8 milhões de $\mathrm{km}^{2}$ (o Brasil tem aproximadamente 8,5 milhões de $\mathrm{km}^{2}$ ), cobrindo oito países soberanos e um espaço ainda sob domínio colonial em pleno século XXI, a Guiana Francesa. Os países soberanos são o Suriname, a Guiana, a Bolívia, o Equador, a Colômbia, a Venezuela, o Peru e o Brasil. No Brasil, a Amazônia abarca cerca de 5 milhões de $\mathrm{km}^{2}$, o que equivale a aproximadamente $54 \%$ do território brasileiro. Um olhar de fora da região, sobretudo dos que têm o poder de dizer o que é o Brasil, quase sempre de São Paulo e do Rio de Janeiro, se esquece de que mais da metade do Brasil é Amazônia. A floresta amazônica é a mais extensa floresta tropical do mundo. 1/6 de toda a água doce do planeta corre na bacia amazônica. Também é o maior banco genético do mundo. Segundo o ex-diretor do INPA, professor Herbert Schubart, em apenas um hectare da Amazônia existem mais espécies vivas do que em todas as florestas do mundo temperado. E no hectare vizinho as espécies não se repetem.

A Amazônia também abriga jazidas minerais entre as mais importantes do planeta (Serra dos Carajás, Serra Pelada, a bauxita de Oriximiná, para ficar com somente algumas). Por dia, são exportadas mais de 100 mil toneladas de ferro só pelo porto de Itaqui, inclusive com energia subsidiada, onde as corporações brasileiro-multinacionais, como a Vale do Rio Doce, pagam pelo quilowatt somente $1 / 33$ do que paga um cidadão brasileiro comum quando acende o interruptor de sua casa. Na região do Complexo Grande Carajás, boa parte das florestas é usada como carvão vegetal para que se faça o ferro gusa e, assim, se exporte o ferro limpo para o primeiro mundo. Considere-se, ainda, a riqueza mineral do Amapá, onde, em 1951, fez-se um acordo para exploração com a U.S. Steel que praticamente exportou todo o manganês do Amapá para os Estados Unidos. Hoje, tem-se um buraco onde antes existia uma jazida de manganês. Lembremos que a Serra dos Carajás é sempre lembrada como a que abriga a maior província 
mineral em exploração do mundo e não pelos indígenas que seu nome evoca ${ }^{1}$.

Quando se fala da Amazônia, temos que ter essa visão de conjunto da riqueza que a região comporta. Ao mesmo tempo, é um desafio analítico que requer uma capacidade de trabalhar com tempos diferentes para poder entender a sua complexidade. Tempos geológicos, geomorfológicos, arqueológicos, históricos e antropológicos.

\section{O tempo geológico}

Para compreendermos a formação da Amazônia em toda sua complexidade, temos que nos remeter a um tempo geológico de 70 milhões de anos atrás. Foi quando se formou o anfiteatro amazônico que podemos imaginar nos colocando nos Andes, na altura do Equador, de frente para o Oceano Atlântico. Esse grande anfiteatro que se forma à nossa frente tem, à esquerda (ao Norte), o Sistema Parima ou Guiano, e, à sua direita (ao Sul), o Planalto Central Brasileiro, ambos geologicamente muito antigos, isto é, das primeiras eras geológicas (Era Primária). A Cordilheira dos Andes formou-se entre 100 e 70 milhões de anos atrás (Era Terciária) e, quando se formou, barrou o fluxo das águas do Atlântico para o Pacífico, que antes corria ao contrário do que corre hoje. Com a formação desse enorme anfiteatro se constitui a Bacia Sedimentar Amazônica. Isso, de 70 milhões de anos para cá. É quando a dinâmica desse ecossistema complexo começa a se desenrolar.

\section{O tempo geomorfológico}

Uma segunda referência temporal que devemos aduzir é a da formação geomorfológica, que se desenvolve após o período entre 18 mil e 12 mil anos. Nesse período, estávamos diante do recuo da última glaciação, glaciação esta que ocupara a latitude que, hoje, corresponde a Nova York e Paris. À época, toda essa área no hemisfério Norte até o Pólo Norte estava coberta por calotas polares. Se imaginarmos a distância onde está a calota polar hoje e a latitude de Nova York e Paris, temos uma idéia da quantidade de gelo que, desde então, derreteu modificando significativamente o clima do planeta. O nível da água do mar subiu 100 metros desde então e por essa causa. É importante considerar esse fenômeno porque, quando hoje se fala em mudança climática global, ela é atribuída exclusivamente ao modelo de desenvolvimento. É preciso ter claro que há mudanças climáticas que não necessariamente foram produzidas pelo homem, muitas das quais ocorreram até mesmo antes de ele aparecer no planeta. A informação sobre o que aconteceu nesse período é muito importante para se compreender uma polêmica que vai se fazer sobre a ocupação da Amazônia hoje.

Durante o período em que essa glaciação estava em seu auge, o clima da Amazônia era mais seco e, assim, a floresta ficara reduzida a alguns nichos topograficamente úmidos diante do clima mais seco geral. Esses nichos, conhecidos como refúgios, acabaram se constituindo em relíquias de bancos genéticos. Quando a glaciação foi recuando e o clima adquirindo as características atuais, ficando mais úmido, a partir destes nichos começa o repovoamento, a recolonização da Amazônia, formando essa floresta densa que existe hoje. Estas áreas de refúgio, estes nichos, alguns deles já identificados, são importantes para qualquer projeto de zoneamento ecológico da Amazônia, posto que foi desses refúgios que partiu toda a recolonização de vida da Amazônia. Por isso, para se discutir a Amazônia, deve-se remontar a 12 mil anos atrás, para compreender muita coisa que está se discutindo aqui e agora, até para evitar uma certa "ideologização" do debate.

\section{Os tempos arqueológico e antropológico}

São importantes as descobertas recentes feitas no município de Manacapuru, a $30 \mathrm{~km}$ de Manaus, de uma cerâmica de seis mil anos atrás. Aqui já nos colocamos num outro tempo, o arqueológico. Essa informação revoluciona todas as teses a respeito da ocupação da Amazônia, antes avaliada em 3.000 anos, como também, ao identificar cerâmicas, indica-nos um certo nível de avanço tecnológico dos povos que ali habitavam. Esses povos foram os primeiros colonizadores da região e são de uma diversidade extremamente grande. Cerca de 180 línguas são faladas ainda hoje na Amazônia, um dos maiores patrimônios

${ }^{1}$ Esse parece ser o destino que as classes dominantes querem para os índios - nomes de ruas, cidades e acidentes geográficos. 
culturais do Brasil e da humanidade. Assim, na Amazônia, além de falarmos de biodiversidade, é importante atentarmos para a diversidade cultural existente na região. Diria que devíamos nos acostumar com a idéia de que existem "Amazônias". Pensar uma região com essa extensão, com essa complexidade, como se fosse homogênea é, no mínimo, um absurdo. Quando chegaram os invasores/colonizadores, os índios da região somavam 3 milhões e 780 mil, segundo as estimativas dos demógrafos. A depopulação gerada pela invasão colonial foi de tal ordem que a população total da Amazônia só viria atingir esse mesmo número em 1970. Hoje, a população da Amazônia brasileira tem aproximadamente 28 milhões de habitantes.

De um ponto de vista de uma política nacional com a região (e não para a região), a problemática indígena coloca-nos desafios até aqui não enfrentados por nenhuma corrente política de modo sério. Afinal, são mais de 180 línguas faladas na Amazônia e isso nos obriga a debater seriamente o que queremos fazer com essa população. Se não somos um país em que o indígena tenha uma expressiva relevância demográfica, como são os casos da Guatemala, México, Nicarágua, Honduras, El Salvador, Peru, Equador, Bolívia, Paraguai e o sul do Chile, o fato de termos a maior diversidade lingüística de todos os países de nuestra América nos impõe uma enorme responsabilidade. São populações que fazem uso comunal da terra-água-solofauna-flora e, embora cada uma delas seja pequena do ponto de vista demográfico, ocupam territórios que agora são alvo de interesses vários (novos, como genoma e água, e antigos, como os minerais, a madeira e a própria terra). Não conheço nenhum partido político brasileiro que tenha enfrentado o desafio de defender esse enorme patrimônio incorporando a diversidade indígena como um valor inegociável.

Considerar os indígenas - e já estamos diante de um tempo antropológico - é fundamental para que possamos acabar com certos mitos sobre a Amazônia, como o do pulmão do mundo e coisas do gênero. A floresta amazônica tem um papel extremamente significativo na biosfera e no planeta, tão significativo quanto outros ecossistemas da mesma envergadura como as florestas temperadas e os oceanos. A Amazônia não tem a primazia de ser a região que, por si só, é responsável pelo desequilíbrio do planeta. Ela faz parte desse equilíbrio junto com outros ecossistemas da mesma dimensão. Mas qual seria a contribuição mais específica da Amazônia? Primeiro, é preciso considerar que a floresta amazônica se encontra no estágio clímax de um equilíbrio dinâmico, quer dizer, uma etapa bastante avançada da sua evolução natural. Esse ecossistema tem um equilíbrio clima/vegetação/solo extremamente delicado e a matriz eurocêntrica de conhecimento, a que hegemoniza nossas universidades, não dispõe de tecnologia apropriada para lidar com ele, na medida em que os complexos tecnológicos que nós conhecemos foram gerados no mundo de clima temperado. É preciso, definitivamente, não desperdiçar o enorme acervo de conhecimentos e os complexos tecnológicos dos povos que habitam a região. Aqui mais do que a inter, ou a multi, ou a transdisciplinaridade, o diálogo de saberes é fundamental para que qualquer projeto de futuro da Amazônia possa dar certo. Ali, há os que dizem "nóis vai e sabe para onde vai" no meio de uma floresta onde, no mínimo, há seis mil anos vivem e são obrigados a conhecer a condição do viver.

Imaginemos essa floresta fantástica que tem, em média, entre 500 e 700 toneladas de biomassa por hectare em 800 milhões de hectares. Três são as razões principais que advêm dessa informação. A primeira diz respeito ao fato de que dessas 500 a 700 toneladas de biomassa por hectare, cerca de 8 a $10 \%$ se recicla todo o ano. Quer dizer, aproximadamente 50 a 70 toneladas de produto líquido anual de biomassa! Só para se ter uma idéia, um hectare de soja com toda a importação de energia de que necessita nos dá aproximadamente 3 toneladas de biomassa anual por hectare. Assim, vemos que a natureza tem uma produtividade biológica primária de 17 a 23 vezes maior que um monocultivo de soja. A sabedoria dos povos originários foi exatamente a de saber conviver com essa produtividade biológica primária e não destruir a floresta. Enfim, souberam conviver com a maior incidência de energia que uma região do planeta recebe, energia essa que tem o tempo de vida do Sol, ou seja, inesgotável nos parâmetros do tempo de vida da História humana. A segunda razão é que cada hectare abriga aproximadamente 70 toneladas de carbono em seus caules, folhas e raízes. Não deixar queimar essa floresta é estar deixando de lançar no ar 70 toneladas de carbono por hectare. Remeto o leitor o exercício de calcular o total de carbono retido na floresta considerando-se que a região tem aproximadamente 800 milhões de hectares.

Em terceiro lugar, consideremos que cada um de nós, assim como cada planta e cada animal, é, em média, constituído de $70 \%$ de água. Essa informação revoluciona a reflexão, porque, quando estamos falando de ciclo da água, esquecemos que quando suamos, transpiramos ou urinamos, 
o ciclo da água age em nós. Esse raciocínio é importante para que não esqueçamos que a sociedade está inserida na natureza. $\mathrm{Na}$ visão antropocêntrica ${ }^{2}$, ainda dominante também entre as esquerdas, o homem deixa de ser natureza. Pois bem, imaginemos essa enorme extensão de florestas da Amazônia sofrendo evapotranspiração todo dia, provocada pela maior incidência de energia solar que essa região do planeta recebe. Com tanta evapotranspiração, podemos falar que a floresta é um verdadeiro oceano verde. Estamos diante da água em estado vivo, enfim, um novo estado da água que, assim, não é somente líquido, sólido e gasoso como nos ensinaram nas escolas. A vegetação da Amazônia não é só resultado do clima, também produz este clima.

Outra informação importante nos vem de pesquisas com radioisótopos sobre a origem da chuva da região que nos dão conta de que, em Belém, $10 \%$ da chuva que cai é evapotranspirada da floresta e $90 \%$ vem do oceano através dos ventos alíseos. Em Tabatinga, no oeste da região, segundo pesquisa do Dr. Enéas Salati, ex-presidente do INPA, registrou-se exatamente o contrário: $10 \%$ da chuva entra diretamente pelos ventos vindos do oceano, enquanto $90 \%$ é chuva que foi reciclada de seis a sete vezes evapotranspirada da floresta. Então, se tiramos a floresta, necessariamente desequilibra-se toda essa dinâmica. É a famosa tese de Gaia, a de que o equilíbrio do planeta depende da vida do planeta. Acaba-se, assim, com uma certa hegemonia dos físicos, para quem o aspecto físico é que determina a vida. Na verdade, há uma relação de reciprocidade e de equilíbrio em movimento. Esse ecossistema fantástico gera umidade por evapotranspiração que, dependendo da estação do ano, se desloca ora para o sul ora para o norte, no jogo das massas de ar. Por exemplo, no nosso verão no hemisfério Sul, a chuva que cai no rio São Francisco, assim como a que cai no sul do Brasil, nesta mesma época, depende da massa úmida que se forma pela evapotranspiração da floresta na Amazônia e se desloca para o sul. Podemos dizer que os sistemas agrícolas que ali se desenvolvem o fazem, mesmo sem o saber, levando em consideração o regime das chuvas que se forma na Amazônia. A plantação de São Paulo depende da chuva da Amazônia e, portanto, depende da floresta, que, por sua vez, está em equilíbrio com aquele processo de evapotranspiração como um todo. O mesmo pode ser dito sobre o verão do hemisfério norte, quando as frentes frias aqui no sul impulsionam essa massa de ar da Amazônia, deslocando-a para a América Central, Caribe, Sul da América do Norte e, assim, regando toda aquela região como, na estação oposta, regara o sul e o sudeste do Brasil. A redistribuição de chuvas no planeta é uma contribuição importante da Amazônia para a dinâmica do ecossistema planetário.

Observemos que problemas novos com relação à soberania se colocam. Assim como não devemos fazer qualquer coisa com a nossa floresta, já que ela atinge nossos vizinhos, a Dinamarca, que exerce a soberania sobre a península do Labrador não poderia, caso pudesse e quisesse, derreter toda aquela extensão de terras sob gelo, pois isso resultaria em sérias conseqüências para todo o planeta. Enfim, a consciência de que vivemos em um mesmo planeta tem que se transformar em uma nova política, e o Brasil dispõe de uma posição especialíssima para se colocar com essas novas perspectivas, desde que abandone a mesma ideologia eurocêntrica desenvolvimentista contra natura. A Amazônia é, assim, um trunfo importantíssimo que os movimentos populares devem incorporar como bandeira no seu processo emancipatório.

Com relação ao solo da floresta, as pesquisas sobre a sua composição química comprovam sua baixa fertilidade, em função da dissolução das bases químicas (cálcio, potássio e sódio) no chamado processo de lixiviação e laterização. Assim, a retirada da floresta expõe o solo ainda mais a tais processos. Todavia, é a floresta que cede ao solo, por meio das folhas, dos frutos, dos insetos, enfim, de todo o conjunto de vida que sobre ele recaia, uma camada de húmus³. Assim, o solo só é pobre se lhes retiramos a floresta que lhe fornece todo o húmus que sustenta essa enorme biomassa (como vimos, entre 500 e 700 toneladas por hectare, sendo que, todo ano, de 8 a 10\% é matéria viva nova). Como vemos, os solos da Amazônia só são pobres sob a perspectiva analítica cartesiana que comanda nossas universidades, haja vista que uma visão holística do solo mostra-o compatível com a floresta que lhe dá toda a matéria orgânica. Mas a visão cartesiana é a que comanda a prática daqueles que

\footnotetext{
${ }^{2}$ Ainda se confunde o antropocentrismo - o homem é a medida de todas as coisas - com o humanismo. É preciso desenvolver um humanismo não antropocêntrico!

${ }^{3}$ Homem deriva do latim homo, humus, aquele que vem da terra.
} 
já vão para a região desmatando-a epistemologicamente porque querem desmatá-la, posto que querem derrubar a floresta para seus pastos, para a soja ou outro cultivo, além da extração da madeira.

Retornemos à questão indígena. Há mais de seis mil anos os índios andam no meio de toda essa floresta, e há autores, como o antropólogo Darell Possey, que nos dizem que a floresta amazônica não é uma floresta exclusivamente natural. As pesquisas desse antropólogo junto aos caiapós e outras comunidades indígenas nos informam que estes índios, na verdade, já retrabalharam a floresta durante milhares de anos. Há cacau na Amazônia, embora não seja nativo da região. O cacau é uma planta afrodisíaca dos astecas. Aceitando-se a tese do povoamento de Abya Yala (América) pela penetração via estreito de Bering, descendo até chegar aos Andes e daí em direção à floresta, o cacau poderia ser uma boa indicação de como os índios foram chegando na Amazônia. Onde tem cacau, teve índio. O mesmo para as palmeiras de ouricuri e de pupunha. Os índios sempre desmatavam dois ou três hectares dessa floresta. Faziam suas queimadas, regulavam estas queimadas, replantavam espécies de interesse nas capoeiras, iam para outro lugar e anos depois voltavam. É por isso que alguns antropólogos afirmam que nós estamos diante de uma floresta cultural tropical úmida, tal a presença do dedo do índio nessa formação. A tradição indígena pode nos dar informações importantíssimas de como conviver com a floresta e não contra a floresta. Como estamos vivendo uma de crise de paradigmas, de referências filosóficas, tecnológicas, políticas e buscamos outros parâmetros de relação com a natureza, essas comunidades são demasiadamente importantes para que possamos trocar informações. São enormes as possibilidades, inclusive econômicas, que derivam do que estamos analisando.

A floresta amazônica guarda produtos e uma série de sabores que são resultantes dessas práticas seculares e dos seus saberes. Em língua portuguesa, "sabores" e "saberes" têm a mesma relação que em francês savoir e saveur, mostrando que o que se sabe também se traduz em sabor (as cozinheiras sabem disso). O sabor traduz isso com perfeição. Uma rede de sorveteria de Belém manipula mais de 125 tipos de sorvetes ao longo do ano. Cupuaçu, taperebá, buriti, açaí, bacaba, graviola entre muitos. A maior parte dos perfumes e de cosméticos que se usa no mundo é tirada de essências da Amazônia desde o séc. XVII. A fama dos perfumes franceses vem das essências de fixação, como o pau-rosa, por exemplo. Nos anos 1980, uma comissão da então União Soviética esteve no Brasil procurando essências para perfumes, e o INPA mostrou, de imediato, que dispunha de 25 já em condições de comercialização e mais de 100 em fase de pesquisa. A Amazônia guarda uma riqueza que a gente sequer conhece. Em um levantamento que pude acompanhar de perto no Acre, no início dos anos 1990, de cada dez espécies de árvores levantadas só três estavam em catálogos mundiais, sendo 70\% desconhecidas. Queimar a floresta amazônica é equivalente a queimar um acervo que desconhecemos, como o da biblioteca de Alexandria, por exemplo. É um patrimônio que aqueles povos que lá vivem souberam guardar e que, ao queimarmos, estamos jogando fora todo um legado de conhecimentos.

É possível traduzir esse conhecimento em políticas públicas. Um exemplo bem objetivo: o Brasil, no início dos anos 1990, quando fiz um estudo para os seringueiros, gastava por ano 1 bilhão e 700 milhões de dólares no programa nacional de merenda escolar, para comprar treze produtos formulados de algumas empresas que ganhavam a concorrência há vinte anos, com alimentos de qualidade duvidosa. Uma amêndoa de castanha, segundo pesquisas bioquímicas, tem todas as proteínas de carne de vaca, tanto que é chamada de carne vegetal, com a vantagem de ser mais facilmente digerida pelo organismo. Duas amêndoas de castanha possuem, em média, o equivalente a um bife de $100 \mathrm{~g}$ de carne. Cada quilo tem 160 amêndoas, ou seja, o equivalente $8 \mathrm{~kg}$ de carne. Portanto, adotando no país um programa nacional de compra de castanha para a merenda escolar, viabilizaríamos comunidades de trabalhadores na Amazônia autogerindo o seu trabalho, melhorando o seu nível de vida. A venda da produção daria mais razão para aqueles povos continuarem vivendo com a floresta e com dignidade. E assim com uma série de outros produtos. Não esquecendo que os sabores não implicam saberes, mas implicam na existência daqueles e daquelas que sabem e, portanto, é dos povos da floresta que estamos falando.

Então, é preciso ter uma política nacional $\mathrm{com}$ e não para a Amazônia, oferecendo linha de crédito para o pequeno produtor que está na Transamazônica, abandonado, produzindo cacau e uma série de coisas e que não tem como escoar sua produção. Há condições reais, há produção, há tradição nesse sentido. O óleo de copaíba, por exemplo, é um excelente cicatrizador.

Devemos entender, definitivamente, que as monoculturas são muito pobres geneticamente falando. Os 
Estados Unidos trabalham com apenas três espécies de trigo, cujos agroecossistemas são tão vulneráveis que precisam de insumos energéticos importados para poder sustentarse, o que os torna muito caros. Assim, um camponês pobre da América Latina é mais rico geneticamente do que eles pela diversidade de espécies com que trabalha. Para se curar diarréia usa-se a folha de uma árvore conhecida, no Amapá, como "preciosa". Essa informação, na mão de uma Bayer ou da Monsanto, é levada para laboratório para que se isole o princípio ativo e, depois, para que este seja patenteado, ignorando todo o conhecimento do camponês ou do indígena. A lei de patentes industriais ignora o knowhow do saber tradicional indígena, que também é saber, que não foi produzido em laboratório e não é propriedade privada, posto que é da comunidade como um todo. Isso inova em termos de direitos. São direitos coletivos, não são direitos apoiados no direito burguês, que é individualizado, privado. Aliás, quem é cientista sério sabe que nenhum conhecimento é produzido exclusivamente por um indivíduo. Só que, sob o capitalismo, sempre se traduz o conhecimento, que é coletivo, em propriedade privada, e isso é uma violação do conhecimento do índio ou do seringueiro. As informações que eles detêm, insisto, são fundamentais. Se fosse necessário fazer um levantamento de espécie por espécie da Amazônia para saber sua utilidade, não haveria dinheiro no mundo para pagar por esse trabalho. Por isso, o roubo, não de espécies, que seria pirataria, mas sim do conhecimento sobre as espécies, o que configura etnobiopirataria, vem sendo amplamente praticado. Insisto: não é de pirataria que se trata, mas sim de etnobiopirataria, o que implica a defesa contra esse roubo, que deve ser a defesa, ao mesmo tempo, desses povos e não simplesmente da floresta. Assim, é fundamental ter clareza em relação a quem seriam os protagonistas de uma outra proposta acerca (e não sobre, também insisto) da Amazônia. Os povos que lá habitam têm uma cultura vasta, uma enorme riqueza acumulada que em muito pode e deve contribuir para um outro mundo possível.

\section{O tempo histórico}

Existe muita desinformação sobre a Amazônia. Em 1611, fundou-se o Forte do Presépio, a nossa Belém de hoje. De lá para cá, houve uma disputa generalizada por territórios que, na Amazônia, sempre se fez por meio de dominação/alianças com comunidades indígenas. Uma aliança com comunidades indígenas era fundamental para os colonizadores poderem fincar a sua bandeira contra uma outra comunidade indígena que, por sua vez, era aliada ou era subordinada a uma outra bandeira colonialista. Não nos esqueçamos de que na Amazônia cinco potências coloniais deixaram sua marca: Portugal, Espanha, França, Holanda e Inglaterra. Portanto, há uma tradição de presença das grandes potências coloniais. A internacionalização, vê-se, não é de hoje. E sempre os índios sendo instrumentalizados em função dessa dominação colonial. A partir do século XVII, houve um processo intenso de descimento do índios para o médio e o baixo curso do Amazonas, destribalizandoos. Inventou-se até uma língua, a dos índios tapuias, índios que, diga-se de passagem, jamais existiram. Tapuia é o nome da língua criada pelos jesuítas. Os índios destribalizados, reduzidos em aldeias e missões, passavam a falar obrigatoriamente essa língua, codificada a partir do tupi-guarani. Eis uma das violências sofridas por esses índios. Isso fez com que eles procurassem os altos cursos dos rios, fugindo desse processo de dominação, tal como os negros escravizados buscavam áreas de difícil acesso, inclusive na floresta, como no Pará, Maranhão e Amapá, onde hoje está a maior parte das comunidades remanescentes de quilombos do Brasil.

A Amazônia não ficou independente em 1822. Em 1822, as elites criollas da Amazônia articularam-se com a metrópole portuguesa e mantiveram-se à parte do processo de independência do Brasil. Para quem não sabe, Portugal mantinha duas unidades administrativas por aqui: a do Vice-reino do Brasil e a Província do Grão Pará (que ia do atual Maranhão até o Amazonas). A Amazônia só vai se tornar independente de Portugal em 1823 incorporandose ao resto do país no velho estilo brasileiro, negociando, por cima, a sua união. Essas elites criollas sabiam que não havia a mínima possibilidade de se controlar o que quer que fosse na região a partir do Rio de Janeiro. Registre-se que o que moveu essas elites criollas era o medo de que, em Portugal, as idéias liberais da Revolução do Porto de 1820 abolissem a escravidão e o latifúndio. Assim, libertandose de Portugal e aderindo ao Brasil, poder-se-ia manter a escravidão e o latifúndio. Assim, o Brasil pôde incorporar um território imenso não para os "de baixo", mas, ao contrário, num pacto político-territorial que se deu mantendo o latifúndio e a escravidão. Vê-se, assim, que uma leitura geográfica de nossa formação social, levando o território a sério, como recomendava Milton Santos, ajuda-nos a me- 
lhor entender a sociedade. Considere-se que, após se verem livres de Portugal, a quem estavam sob controle até 1823 , as elites desencadearam um massacre inusitado sobre os povos indígenas, a ponto de terem gerado, 12 anos depois, em 1835, a maior revolução popular da história do Brasil, a Cabanagem. Uma revolução que, dadas as circunstâncias da época, foi separatista. Cabanagem vem de cabana, enfim, de pessoas simples e pobres que, na verdade, resistiram à violência que sucedeu a independência. De Belém, do alto Madeira ao alto Solimões, a revolução dos cabanos, dos simples, juntou índio, branco pobre e negro. Um só exemplo: os índios Mundurucus, que habitavam a região entre os rios Madeira e Tapajós, somavam 56 mil índios em 1826 e, em 1855, haviam sido reduzidos a 3.200, porque tinham apoiado a Cabanagem. Um massacre sem igual em nossa história.

A partir de 1870, depois de os europeus terem descoberto a vulcanização, a borracha se tornaria importante. Em 1877, após o massacre que houvera, não havia como explorar essa riqueza, que a natureza ofertara e a cultura indígena já manipulava ${ }^{4}$, simplesmente porque não havia gente para trabalhar. Esse período coincide com a seca nordestina, e, com isso, uma vaga de nordestinos é atraída à Amazônia para extrair a borracha. Importante: nessa mesma época o café estava no auge de sua expansão no vale do Paraíba e já entrando no Planalto Paulista, mas nem por isso o nordestino optou por vir para o sul, mas, sim, por ir para a Amazônia. Para se entender essa opção, há que se considerar que nas relações de trabalho predominantes nos sertões de gado nordestino não havia trabalho escravo, como nas fazendas de café do sul e sudeste. Assim, se a seca explica a razão imediata da migração, não explica a opção pela Amazônia e não pelos cafezais do sudeste brasileiro. A Amazônia aparece no imaginário do nordestino como terra da liberdade, e isso conforma parte da subjetividade do homem amazônico, tal como o do escravo que fugia da fazenda escravocrata. É claro que não foi a liberdade que o migrante encontrou na Amazônia, mas sim um sistema de aviamento, um sistema de barracão. Detalhe: os donos dos seringais, os seringalistas, não eram donos da terra, que recebiam como concessão para extrair látex, já que eles mesmos não tinham interesse em ser donos da terra, porque faziam uma exploração predatória, o que os impelia a buscar outra área mais adiante. Assim, chegou-se ao Acre. Isso é parte da complexa questão fundiária na Amazônia, onde poucos, mas muito poucos mesmo, podem provar, legitimamente, a propriedade das terras que ocupam, porque, na verdade, não havia título da terra, e sim concessão para extrair o látex.

\section{O tempo atual, onde todos os tempos atuam}

Ofereço mais um conjunto de datas que, acredito, nos ajude a entender a conformação do atual processo de ocupação da região: 1962, 1965, 1967 e 1970. Essas datas têm significação própria. 1962 é o ano da abertura da Rodovia Belém/Brasília, que inaugura a era das grandes estradas na Amazônia. 1965 é quando o governo militar concede à Força Aérea dos Estados Unidos o privilégio de fazer o levantamento aerofotogramétrico do país. Eles localizam minérios até então desconhecidos. Em 1967, temos um "duplo fato": a inauguração da Zona Franca de Manaus junto com a inauguração, também em Manaus, do COMAR - Comando Militar da Amazônia, inaugurando-se, assim, o "modelo postiço" ou "modelo prótese", na medida em que é um modelo externo e que não tem nada a ver com a região. Quando se chega em Manaus, é surpreendente o que se vê já no aeroporto: quem nos dá boas vindas é a Yamaha, a Westinghouse, enfim. Não esqueçamos que junto com a Zona Franca se criou o COMAR.

Na Amazônia convivem dois padrões sociogeográficos. De um lado, um padrão antigo que se organiza através do rio. De outro, o padrão que se estrutura a partir da estrada, inspirado em razões geopolíticas, que nos deu, por exemplo, a rodovia Transamazônica, em 1970, com o PIN - Programa de Integração Nacional. Esse padrão inaugura a fase atual de violência e devastação da Amazônia. É a Transamazônica, a Cuiabá-Santarém, a Cuiabá-Porto Velho, a Porto Velho-Manaus e a Manaus-Caracas, enfim, as rodovias que cortam a Amazônia com absoluto desdém pelos ecossistemas e seus povos. Aliás, à época dizia-se que a Amazônia precisava ser ocupada, ignorando-se, assim, não só a ocupação milenar como a do período colonial.

\footnotetext{
${ }^{4}$ Os índios usavam amplamente a borracha para fazer, entre outras coisas, panos e bornais impermeabilizados, o que não é qualquer coisa diante das chuvas amazônicas.
} 
Começa, então, o período dos grandes projetos hidrelétricos e de exploração mineral subsidiados com incentivos fiscais. Ficou famosa a declaração do ditador Garrastazu Médici, em 1970, ao propor a Transamazônica: "o Nordeste é um lugar de homens sem terra, e a Amazônia um lugar de terra sem homens". Essa frase justificava que se trouxessem os homens que não tinham terra para o lugar em que não havia homens. Com isso, mantém-se o latifúndio no Nordeste da mesma forma e, ao mesmo tempo, começa um processo de modernização/colonização agrícola que vai levar o paulista, o catarinense, o gaúcho, o paranaense, também para a Amazônia. A região recebe esse impacto, que, no fundo, gera uma série de outros problemas. Problema do desmatamento, do financiamento dos grandes pecuaristas, da extração de madeira e do garimpo. Se fizermos um perfil sociológico de quem é o garimpeiro, verificaremos que normalmente é um colono, um posseiro, um pequeno proprietário. Portanto, a questão do garimpo também remete à questão fundiária, da mesma forma relacionada à situação dos indígenas, que têm suas terras invadidas.

O que talvez os militares não esperassem é que, por coincidência, o impacto sobre o ecossistema amazônico tenha se dado em um momento em que se começava a criar uma consciência planetária em torno da ecologia, e que dentro da mata não houvesse, como nas florestas européias, duendes e gnomos. Lá dentro havia seringueiros, castanheiros, buritizeiros, açaizeiros, balateiros, quilombolas e indígenas, enfim, uma série de populações camponesas/extrativistas e de povos que começaram a resistir contra esse processo de ocupação e que constataram, com sabedoria, por meio de algumas lideranças, que o movimento ambientalista era um aliado. Eles, que lutavam pela terra e pela floresta, encontraram lá fora o eco que não encontravam na sociedade brasileira. Por isso, Chico Mendes foi o primeiro líder sindical assassinado que gerou comoção mundial. Chico Mendes era um homem de uma de visão aberta que percebeu que a questão social, sobretudo a questão da terra, estava exigindo uma nova dimensão de preservação da floresta, já que a floresta também era importante não só para os camponeses mas também para o planeta. Articulou o local ao global. Começou a construir, a partir de dentro da mata, um projeto que apontava para um futuro diferente para a Amazônia, aliando os seringueiros aos índios. Quando um índio sai por aí gravando a palavra de branco, como o ex-deputado Juruna, é preciso atentar para o significado político deste ato: a palavra tem um valor muito grande para os indígenas, aliás como para todo povo ágrafo (que não escreve). A palavra dita é tudo que têm para se fazerem acreditados. Então, usam a tecnologia do branco, o gravador, para firmar um valor que é seu. Palavra de índio é palavra honrada. Assim, surgem na Amazônia possibilidades verdadeiramente inovadoras: juntar os valores da tradição com o que se chama modernidade: uma modernidade indígena e camponesa, termos quase sempre antagonizados. Recentemente no Equador se incorporaram, pela primeira vez na Constituição de um país, os Direitos da Natureza, o que valeu artigos de Eduardo Galeano e Boaventura de Sousa Santos, chamando a atenção para o caráter revolucionário que a proposta comporta. Cabe lembrar que a natureza é uma condição geral da existência humana, e, como Marx alertara na sua Crítica ao Programa de Gotha, que não é só o trabalho que cria riqueza, mas que a natureza é riqueza (não confundir com valor no sentido capitalista do termo).

Enfim, é preciso respeitar as diferenças dos povos com suas diferentes matrizes de racionalidade. A verdadeira e irrenunciável soberania sobre o território amazônico não é incompatível com o reconhecimento dos direitos dos povos indígenas e dos camponeses que há muito habitam a floresta e as regiões ribeirinhas. Ao contrário, é sua condição, até porque a soberania, além de territorial, é popular (todo o poder emana do povo e em seu nome será exercido) e os indígenas e camponeses são parte constitutiva do povo brasileiro. Assim, uma visão de soberania que ignore sua dimensão popular é inconsistente, embora não faltem os que assim pensam (o recente debate sobre as terras indígenas de Raposa Serra do Sol une a direita mais reacionária aos comunistas nacionalistas contra os direitos dos povos indígenas e camponeses, inclusive quilombolas). Além de tudo, essa visão antipopular da soberania ignora avanços relevantes já consolidados nas leis do país, como o de que as áreas indígenas são terras da União e, como tal, são de pleno direito do estado e condição para que se zele pela unidade territorial do país, o que não seria garantido caso fossem destinadas aos latifundiários, como está acontecendo ao arrepio da lei nas fronteiras do Rio Grande do Sul com a presença de empresas multinacionais de monoculturas de madeira.

Sempre que se debate a Amazônia, parece que todo brasileito é tomado por precauções de soberania. Defender a Amazônia é tão importante como defender o baião, o xote, o chorinho e o samba, mas não porque sejam brasileiros, e sim 
porque no dia em que estes ritmos acabarem, a humanidade fica mais pobre. A mesma coisa vale para o tango, a polca, o jazz, para o rock e para a valsa. Ou seja, a humanidade dança e sente diferente, seu patrimônio é a diferença. A sociedade ocidental não soube conviver com a diferença; ao contrário, ignorou-a. Vivemos um momento importante para avaliar o que foram cinco séculos de impacto civilizacional sobre os outros povos e outras terras que não a Europa e suas áreas de desdobramento hegemônico (Estados Unidos, Canadá, Austrália e Nova Zelândia). Cada povo tem um modo próprio de viver, inclusive o direito de continuar vivendo do jeito que melhor lhe aprouver. Alguns dizem que eles têm direito ao desenvolvimento. Sim, desde que sejam eles que escolham o querem do desenvolvimento, que bem pode ser um gravador para afirmarem seu valor à palavra. Enquanto existirem Yanomami, Tikuna, Apurinãs e uma série de outras comunidades camponesas, há uma possibilidade de se aprender a conviver com essa diferença. A sociedade ocidental tem transformado a diferença em hierarquia: a diferença que a natureza produziu em branco e preto foi transformada em racismo, em um processo que coloca um como superior e o outro como inferior. A diferença homem/mulher se transformou em machismo, hierarquizando-se enquanto uma superioridade do homem sobre a mulher. E assim se deu com os povos, hierarquizando-os como se houvesse uma linearidade que iria dos povos mais simples até os mais complexos, que seria a civilização industrial européia.

Toda essa luta que vem sendo travada pelos povos indígenas, desde o primeiro momento de contato com o invasor/colonizador, e por muitos de nós, sobretudo depois de 1968, trouxe, como resultado, no Brasil, um significativo aumento da população indígena: de 180 mil, avaliados em finais dos anos setenta, temos, hoje, aproximadamente, 800 mil!

Assim, para se entender a Amazônia, é preciso construir uma nova visão, eco-socialista, tal como Chico Mendes propusera. Enfim, buscar uma sociedade que tenha outras relações sociais que apontem para a justiça e a igualdade entre os homens e as mulheres, sobretudo convivendo com a radicalidade da democracia. Um eco-socialista não quer só novas relações sociais e de poder entre os homens e mulheres, mas também novas relações com a natureza. Por exemplo: a lâmpada fluorescente foi inventada pela Philips, em 1937, com uma durabilidade de 10 mil horas (o que significa dizer que se você a ligasse hoje, ela iria queimar daqui a quatorze meses), mas só foi lançada no mercado quatro anos depois, com uma durabilidade de apenas mil horas. Houve pesquisa não para aumentar o tempo de duração da lâmpada, ao contrário! Toda a humanidade poderia ter, hoje, lâmpadas estocadas e os trabalhadores que estivessem trabalhando neste setor poderiam desenvolver atividades em outros setores, e assim todos poderiam trabalhar menos e ter todas essas coisas. Enfim, a humanidade já alcançou, pelo menos nessa atividade, um tal nível de desenvolvimento que ninguém deveria se dedicar a essa atividade. A natureza também agradeceria. Precisamos aprender um pouco que seja com uma determinada tribo do Mato Grosso, que trabalhava 5 horas por dia e, ao receber um machado de presente, começou a produzir o mesmo em apenas 2 horas. Na sua matriz de racionalidade, continuaram trabalhando só duas horas e tiveram mais tempo para dançar, para namorar, passear, enfim, para poder desenvolver a sua fantasia, a sua criatividade, sua pulsão ao maravilhoso (Bataille). Afinal, o negócio que a burguesia inventou e tanto preza é, rigorosamente, a negação do ócio (neg+ócio). A verdadeira riqueza é o tempo livre para os encontros e não o time is money. A riqueza não é o dinheiro, o dinheiro no máximo expressa a riqueza, mas não é a riqueza mesma. A riqueza é o tempo. Não nos iludamos com a idéia de que a humanidade, com seus já quase 7 bilhões de habitantes, pode prescindir do conhecimento e da tecnologia ocidentais. Não se trata de opor essas diferentes tradições. A China, com seus quase 1 bilhão e meio de habitantes, tem uma medicina com base em raízes, ervas e chás. Há um esforço legítimo de aproximar diferentes matrizes de racionalidade, assim como os físicos quânticos souberam se inspirar nas tradições orientais, confessadamente na deusa Shiva, como Heisenberg fez. Os indígenas têm dado provas cabais dessa apropriação de outras tradições e, não fosse essa flexibilidade cultural, com certeza eles não estariam aqui hoje reivindicando seus direitos de ser diferentes mas não isolados.

Todo esse patrimônio cultural e natural representado pela Amazônia só poderá ser devidamente valorizado se conseguirmos entender que a verdadeira ameaça a esses patrimônios vem de uma sociedade cuja relação com a natureza e as outras matrizes de racionalidade é de submetê-las aos desígnios de acumulação, transformando tudo em recursos a serem explorados na medida em que transforma valores em preços, e os preços, sabemos, são medidos abstratamente por números que não têm limites. Assim, com essa compreensão de 
fundo, devemos ser capazes de traduzir a questão da Amazônia em propostas concretas como, por exemplo, a convicção de que a reforma agrária nos países que detêm a soberania sobre a Amazônia é fundamental, não só para evitar a pressão migratória dos expropriados para a região, como também para encontrar as formas específicas de ordenamento territorial na própria região para o que os movimentos sociais já apontaram criativamente com as Reservas Extrativistas, que bem podem abrir novas possibilidades de incorporar as tradições originárias (indígenas), camponeses e quilombolas nas unidades de conservação, respeitando, assim, toda a contribuição milenar que esses povos já deram e que essas populações camponesas (ribei-

\section{Referências}

CUNHA, Lucia Helena de O. Diálogo de saberes entre tradição e modernidade: ordens e desordens. In: REUNIÃO BRASILEIRA DE ANTROPOLOGIA, 26., 2008. Porto Seguro, Bahia, 2008.

Diálogo de Saberes na Pedagogia Ambiental - transpondo dicotomias. In: CONGRESSO IBEROAMERICANO, V., 2006. Brasil, Anais. Programa de Formación Ambiental de América Latina y Caribe. México: PNUMA, 2007.

Entre o mar e a terra: tempo e espaço na pesca em Barra da Lagoa. Dissertação (Mestrado). São Paulo: PUC, 1987.

DIEGUES, Antonio Carlos S. (Org.). Desmatamento e modos de vida na Amazônia. São Paulo: NUPAUB-USP, 1999.

EMPERAIRE, Laure (Org.). A floresta em jogo: o extrativismo na Amazônia Central. São Paulo: UNESP, s/d.

GONÇALVES, Carlos Walter P. Geografando nos varadouros do mundo. Brasília: IBAMA, 2003.

Geografias, movimientos sociales, nuevas territorialidades y sustentabilidad. México: Siglo XXI, 2001. Amazônia Amazônias. São Paulo: Contexto, 2001.

. Diálogo de diferentes matrizes de racionalidade. Rio de Janeiro: Universidade Federal Fluminense, 2007. Inédito. rinhos, seringueiros, quilombolas, castanheiros, balateiros, etc.) legaram.

A Amazônia bem pode nos inspirar novas e outras perspectivas para o devir da humanidade. Se a natureza é sempre invocada quando debatemos a Amazônia, não desconsideremos que, no fundo, é da natureza de nosso devir que estamos falando. Enfim, o que fazer com o outro, seja esse outro a natureza, seja esse outro os povos que são diferentes, rigorosamente entes que diferem de nós? A crise que vivemos é mais que uma crise do capitalismo, embora o seja. É uma crise civilizacional, cuja transformação se dá num tempo longo. Como nos ensinam os chineses, "toda longa caminhada começa com o primeiro passo".

GOULD, Stephen J. Seta do Tempo, ciclo do tempo: mito e metáforas na descoberta do tempo geológico. São Paulo: Companhia das Letras, 1991.

LEFF, Enrique. Racionalidade ambiental: a reapropriação social da natureza. Rio de Janeiro: Civilização Brasileira, 2006.

Saber ambiental: sustentabilidade, racionalidade, complexidade, poder. Petrópolis, RJ: Vozes, 2001.

RICOEUR, Paul et al. As culturas e o tempo: estudos reunidos pela Unesco. Petrópolis: Vozes; São Paulo: Editora da Universidade de São Paulo, 1975.

SANTOS, Milton. A noção de tempo nos estudos geográficos. In: Por uma Geografia Nova - da crítica da geografia a uma geografia crítica. São Paulo: Editora da Universidade de São Paulo, 2002.

. A natureza do espaço, técnica e tempo, razão e emoção. 2. ed. São Paulo: Hucitec, 1997.

WHITROW, G. J. O tempo na história: concepções do tempo da pré-história aos nossos dias. Rio de Janeiro: Jorge Zahar Editor, 1993. 